\title{
Microsoft PowerPoint Media Use and Student Learning Motivation in Islamic Religious Education
}

\author{
Asep Sulaeman' \\ DOI: 10.35445/alishlah.v13i3.1468
}

\begin{abstract}
Article Info
Abstract

Keywords:

Powerpoint, Use of

Media, Computers,

Learning Motivation

This study aimed to analyze using Microsoft Powerpoint computer media on students' learning motivation in Islamic Religious Education subjects. The approach used in this study is quantitative. The data used in this study, namely the use of Microsoft Powerpoint media and students' learning motivation in religious education at a private Junior High School in Garut Regency, was analyzed in the form of statistical data. The method used in this research is the descriptive method. Based on the data analysis, it can be concluded as follows: 1) The use of Microsoft PowerPoint media is well proven and reduce verbalism, teaching materials are more transparent in meaning; 2) The more explicit motivation of students is in the excellent, as evidence by excellent results of research on the indicators of being diligent, tenacious, happy to work independently, confident and happy to find and solve problems showing a number 4.09. This figure is in the interval $3.5-4.5$, including good category; and, 3) The use of Microsoft PowerPoint media on students' motivation to learn is good. It is proven that the study results show that $57 \%$ is in a suitable category. As for $43 \%$, it is influenced by other factors.
\end{abstract}

Kata kunci:

Powerpoint,

Penggunaan Media,

Komputer, Motivasi

Belajar

\begin{abstract}
Abstrak
Penelitian ini bertujuan untuk menganalisis penggunaan media komputer Microsoft Powerpoint terhadap motivasi belajar siswa pada mata pelajaran Pendidikan Agama Islam. Pendekatan yang digunakan dalam penelitian ini adalah kuantitatif. Hal ini dikarenakan data yang digunakan dalam penelitian ini yaitu penggunaan media Microsoft Powerpoint dan motivasi belajar siswa pada pendidikan agama di salah satu SMP swasta di Kota Garut, akan dianalisis dalam bentuk data statistik. Metode yang digunakan dalam penelitian ini adalah metode deskriptif. Berdasarkan analisis data dapat disimpulkan sebagai berikut: 1) Penggunaan media komputer Microsoft PowerPoint terbukti baik dan mengurangi verbalisme, bahan ajar lebih transparan makna; 2) Motivasi siswa yang lebih eksplisit berada pada tingkat sangat baik, terbukti dengan hasil penelitian yang sangat baik pada indikator rajin, ulet, senang bekerja mandiri, percaya diri dan senang menemukan dan memecahkan masalah menunjukkan angka 4,09. Angka tersebut berada pada interval 3,5-4,5 termasuk kategori baik; dan, 3) Penggunaan media Microsoft PowerPoint terhadap motivasi belajar siswa sudah baik. Terbukti hasil penelitian menunjukkan bahwa 57\% termasuk dalam kategori sesuai. Adapun $43 \%$ dipengaruhi oleh faktor lain.
\end{abstract}

\footnotetext{
${ }^{1}$ Universitas Islam Negeri Sunan Gunung Djati, Bandung, Indonesia

Email: asepsulaimano85@uinsgd.ac.id
} 


\section{INTRODUCTION}

There are many ways people learn throughout their lives and in every situation. As a human being, education plays a significant role in shaping your character. Education is essential to shaping a person by established norms (Susanti et al., 2020). In light of this fact, the government is taking education extremely seriously, believing that a robust education system will produce the next generation of quality citizens capable of adapting to life in society, nation, and state (Nugraha et al., 2021). Globalization has led to a demand for a new education system that can produce the human resources needed for a rapidly evolving world (Dewi \& Izzati, 2020).

Today's technological advancements have been astounding. Numerous aspects of life have benefited from technological progress. Its existence has profoundly affected human life in various ways and dimensions (Kusrini et al., 2018). Advances in technology and information have also triggered changes in the learning system, namely efforts to free the world of education from the confines of conventional learning models (Irfan \& Ristiana, 2019). Learning is a complex process that occurs throughout an individual's life. The learning process occurs due to an individual's contact with his environment. As a result, learning can occur anytime and in any location. A change in conduct is one indication that someone has learned. Learning tactics that engage students are student-centred, not teacher-centred (Syaepudin \& Juhji, 2020). Fun learning can occur if the interpersonal relationship between teachers and students goes well. There are many ways to make the learning atmosphere fun. Fun learning can be achieved because students are active during the learning process (Asriningsih et al., 2021). In addition, interest in learning also contributes to the happy atmosphere of learning. So that interest in learning remains high, teachers need to provide feedback on learning outcomes that have been achieved or tasks that students have completed (Widodo et al., 2021; Prayitno \& Mardianto, 2020).

Along with selecting appropriate learning tactics and methods, it can be aided by using relevant learning media to foster student-centred learning, engage students, and foster a pleasant learning environment (Salmihah et al., 2021). The term "learning media" refers to all software and hardware that can be used to communicate the content of teaching materials from learning resources to learners (individuals or groups), stimulating the learners' thoughts, feelings, concerns, and interests in such a way that the learning process (in/in/out) outside the classroom becomes more effective (Damayanti \& Qohar, 2019).

Science and technical advancements increasingly motivate renewal efforts in using technological outcomes in the learning process. Teachers must be able to utilize the tools offered by the school, which may or may not reflect current trends and desires (Anomeisa \& Ernaningsih, 2020; Hikmah \& Maskar, 2020). At the very least, teachers can employ inexpensive and efficient instruments that, while modest and straightforward, are necessary for achieving learning objectives. Thus, it can be argued that media is an integral part of the teaching and learning process to accomplish educational goals in general and school-based learning objectives in particular (Ningsih, 2020). Human science should be used as a tool to achieve the welfare of all creatures by making the best use of it, one of which is using computer media in learning (Astiti \& Saputra, 2021).

Considering that the results of learning Islamic Religious Education have been deemed lacking, the media's presence has a significant meaning in the teaching and learning process. There is a lack of attention paid to other aspects of the learning process, such as the use of teaching methods. Without media that can give students a clearer picture of what they're learning, it's difficult to meet learning goals. Learning media must be included in teaching and learning because their role as media presenter (message distributor) has unique potentials for motivating students to learn and acting as a teaching aid, and substituting for certain responsibilities of the teacher in the process.

The media can represent what the teacher cannot say through certain words or sentences; even the abstractness of the material can be concreted with the presence of the media. The use of computer media will make it easier for students to receive and remind the material that has been delivered. 
Another benefit, it will make it easier for teachers to store material because it can be grown directly to students. A piece of concrete evidence in the form of tools and moving images because these media are directly related to the senses of sight and hearing.

The role of the media is emphasized in the three features of teaching media, namely: 1) Media can capture, store and re-display an object or event; 2) Media can re-display objects or events in various ways according to needs, and 3) Media can display an object or event that contains meaning. It should be noted that information technology has developed very rapidly. Information technology must be realized to create various ways to facilitate information delivery, such as PowerPoint program technology. It is interesting to explain Islamic Religious Education material to students using PowerPoint program learning media in learning. Microsoft PowerPoint is one of Microsoft's applications, and Microsoft Word and Microsoft Excel are well known to many people. These three applications are commonly called Microsoft Office. The Microsoft PowerPoint application serves to assist users in presenting presentations. The PowerPoint tool includes slide capabilities for delivering essential topics of conversation to the pupils. A slide can be animated in an intriguing way using animation capabilities. Similarly, resources such as front images, sound, and effects can create an effective slide. This slide product can entice listeners to accept our kids' information when it is given. When teachers use computer media, particularly the Microsoft PowerPoint program, they must exercise caution in selecting and identifying the media to motivate pupils to study, as not every student is familiar with it.

The use of PowerPoint as a teaching medium has been studied by a number of researchers in the past. The impact of PowerPoint on student learning was examined by Baker (2018). Mansoer (2019) studied the impact of PowerPoint presentations on student achievement and information retention in English language teaching. PowerPoint presentations were studied by Hadiyanti (2018). This research is different from previous research. It was found that using PowerPoint as a teaching tool in Islamic religious education had a statistically significant impact on student learning motivation.

\section{METHODS}

Quantitative methods are employed in this study. Students in Islamic religious education at Muhammadiyah Karangpawitan Junior High School were asked to complete a survey about their motivations for learning through the use of Microsoft Powerpoint computer media. This study employs a descriptive research design (Suriati et al., 2020). Qualitative and quantitative data were collected in this study for the purposes outlined above. This study relies on quantitative and qualitative data rather than relying solely on quantitative information. Students completed a survey that yielded quantitative data, then processed it through statistical analysis. Researchers gathered qualitative data by interviewing, observing, and documenting participants, and then using logical analysis, or rational reasoning and assessment based on the results of the readings, to synthesize the information. Data analysis in this study relies on a quantitative approach that employs normality tests and correlation analysis to examine the relationships between variables.

\section{FINDINGS AND DISCUSSION}

Based on the data from the questionnaire distribution, the distribution of the data obtained is as follows:

Table 1. Distribution of research data

\begin{tabular}{|l|l|l|l|l|}
\hline 54 & 56 & 56 & 57 & 58 \\
\hline 59 & 59 & 59 & 59 & 59 \\
\hline 60 & 60 & 60 & 60 & 60 \\
\hline 61 & 61 & 62 & 62 & 62 \\
\hline 62 & 62 & 62 & 64 & 64 \\
\hline 64 & 64 & 65 & 65 & 65 \\
\hline 67 & 68 & 69 & & \\
\hline \multicolumn{6}{|c|}{ Source: data proceed } \\
\hline
\end{tabular}


Test the Normality of Variable $\mathrm{X}$ with the following steps:

$$
\text { Mean: } \bar{X}=\frac{\sum \mathrm{X}}{\mathrm{n}}=\frac{2025}{33}=61,36
$$

Finding the Range of Variable $\mathrm{X}$ is the most significant score minus the smallest score, then the range is $R=x_{\text {makx }}-x_{\text {min }}$

$$
\mathrm{R}=69-54 \quad \mathrm{R}=15
$$

The number of Classes is calculated by the following formula:

$$
\begin{aligned}
& \mathrm{k}=3,3 \log \mathrm{n}+1 \\
& \mathrm{k}=1+3,3 \log \mathrm{n} \\
& \mathrm{K}=1+3,3 \log 33 \\
& \mathrm{k}=1+3,3(33) \\
& \mathrm{K}=1+3,3=6 \text { (rounded to } 6)
\end{aligned}
$$

Looking for Class Intervals

$$
\mathrm{p}=\frac{r}{k} \mathrm{P}=\frac{15}{6}=2,5 \text { (rounded to } 3 \text { ) }
$$

Class Limit

\begin{tabular}{cc} 
Table 2. Frequency & Value of Variable $\mathbf{X}$ \\
\cline { 2 - 2 } Score & Frequency \\
\hline $54-56$ & 3 \\
$57-59$ & 7 \\
$60-62$ & 13 \\
$63-65$ & 7 \\
$66-69$ & 3 \\
Amount & 33 \\
\hline
\end{tabular}

Based on the table above, the lower class limit and the upper class limit are as follows:

$\begin{array}{ll}\text { Class lower limit } & : 54,57,60,63,66 \\ \text { Class upper limit } & : 56,59,62,65,69\end{array}$

High-end Midpoint

- The first class is $: \frac{54+56}{2}=55$

- The second class is $: \frac{57+59}{2}=56$

- The Third class is $: \frac{60+62}{2}=61$

- The Fourth class is $: \frac{63+65}{2}=64$

- The Sixth class is $: \frac{66+69}{2}=67$

The average of the variables $\mathrm{X}: \overline{\mathrm{X}}=\frac{\sum \mathrm{X}}{\mathrm{n}}=\frac{2025}{33}=61,36$ So, the mean median is 61.36. Next, to find the average deviation of the grouped data using the formula: $S R=\frac{\sum f_{i\left|X_{i-\bar{x}}\right|}}{\sum F_{i}}$

Table 3. Data deviation

\begin{tabular}{cccccc}
\hline Score & Frequency & Xi & Fi Xi & $|X i-\bar{X}|$ & Fi $|X i-\bar{X}|$ \\
\hline $54-56$ & 3 & 55 & 165 & 6.36 & 19.08 \\
$57-59$ & 7 & 56 & 392 & 5.36 & 37.52 \\
$60-62$ & 13 & 61 & 793 & 0.36 & 4.68 \\
$63-65$ & 7 & 64 & 448 & 2.64 & 18.48 \\
$66-69$ & 3 & 67 & 201 & 5.64 & 16.92 \\
Amount & 33 & 303 & 1999 & 20.36 & 96.68 \\
\hline
\end{tabular}

Source: data proceed 


$$
\begin{gathered}
=\frac{\sum F_{i X_{i}}}{\sum F_{i}}=\frac{1999}{33}=60,5 \\
S R=\frac{\sum f_{i\left|X_{i-\bar{x}}\right|}}{n}=\frac{96,68}{33}=2,92969697 \text { (rounded to 3) }
\end{gathered}
$$

\section{Research Variable Correlation Analysis}

To find out the strength of the correlation or the high and low correlation. Then, the variable $\mathrm{x}$ "Use of Microsoft PowerPoint Media" and the variable y "Learning Motivation of Students." So the values, when consulted or compared roughly into the "Product moment" interpretation table, are as follows:

\begin{tabular}{cc} 
Table 4. Interpretation of the product-m \\
\cline { 2 - 2 } Correlation & Conclusion \\
\hline$<-0,20$ & slight \\
$0.21--0.40$ & low \\
$0.41--0.60$ & moderate \\
$0.61--0.80$ & high \\
$0.81--1.00$ & very high \\
\hline \multicolumn{2}{r}{ Source: data proceed }
\end{tabular}

1) From the table above, it can be concluded that there is a relationship between the variable $\mathrm{X}$ "Use of Microsoft PowerPoint Media" and the $\mathrm{Y}$ variable, "Student Learning Motivation" because the value of $\mathrm{rxy}=0.90$ which lies between $0.70-0.90$ interpretation is a "very strong correlation". tall."

2) The correlation is very high based on the influence of scientific and technical progress, which encourages reform efforts in using technology results in the learning process Determining the test of the effect of the $\mathrm{X}$ variable on the $\mathrm{Y}$ variable

To find out the size of the influence of the variable $\mathrm{X}$ on the $\mathrm{Y}$ variable first, the degree of absence of correlation will be calculated using the formula:

Determining the degree of non-correlation

$$
\begin{aligned}
\mathrm{K}=\sqrt{1-r^{2}} \\
=\sqrt{1-0,90^{2}} \\
=\sqrt{1-0,81}=\sqrt{0,19}=0,43
\end{aligned}
$$

Determine the magnitude of the effect of changes in variable $x$ on variable $y$

$$
\begin{aligned}
\mathrm{E}=100 & (1-\mathrm{K}) \\
& =100(1-0,43)=57 \%
\end{aligned}
$$

From the calculation above, the degree of change in the $\mathrm{X}$ variable to the $\mathrm{Y}$ variable reaches $57 \%$, which means that there are still $43 \%$ of other factors that influence the learning motivation of Muhammadiyah Junior High School students Karangpawitan Garut. This is in line with Baker's research (2018) that found students learn more when taught the same material using PowerPoint.

Microsoft PowerPoint is a multimedia-based presentation application optimized for delivering presentations, making it an attractive communication medium. Various text, colour, and image processing capabilities, as well as animations that can be treated according to the user's imagination, are only some of the features that make this medium intriguing to use as a presenting tool Not always PowerPoint can be used easily by everyone, including in the World of Education. Therefore, below are the obstacles-lack of mastery of Information Technology. Hadiyanti (2018), in her research, state that PowerPoint Presentation is now quite common in many aspects of life, not only at schools. It facilitates although it was occasionally blamed as not engaging or even boring

Learning methods using learning media and presentation methods lately are often used to implement the learning process because they are considered effective in delivering learning materials. Besides being effective in providing it, it can also increase students' creativity and learning 
motivation. The Projector learning media with a PowerPoint presentation program will awaken students' motivation and make it easier to accept and understand the subject matter of Information and Communication Technology learning. One of the factors that influence learning outcomes is the presentation of teaching materials used to influence children's motivation because the production of learning is very important in one's success in learning. In learning using PowerPoint media, there is an agreement between students about collaborating. Problems solved together will be concluded together. The teacher's role is only as a facilitator who directs students to achieve learning goals. Learning using PowerPoint media can attract students' attention to be active in learning. And can increase student learning motivation. In this case, the improvement happened not only by applying PowerPoint as learning media but also by the activity in learning. It is in line with Tsai (2020), who found that students who received web-mediated Meaningful Learning significantly increased their learning engagement. However, the expected effects of Activity Based Learning on developing students' skills in using PowerPoint and Word, learning engagement, and academic motivation were not found.

\section{CONCLUSION}

Based on the data and analysis, it can be concluded as follows: 1) The use of Microsoft PowerPoint media in SMP Muhammadiyah Karangpawitan, Garut Regency is proven to be good and reduces verbalism, teaching materials are more explicit in meaning; 2) Students' learning motivation at SMP Muhammadiyah Karangpawitan, Garut Regency is good, as evidenced by the results of the research on indicators of being diligent, tenacious, confident and happy to take essential wing education: $15: 33$ ) $=4.09$. This figure is in the PowerPoint interval, including the very good category; and 3) The use of computer media Microsoft PowerPoint on students' motivation to learn book titles is good. Proven research results show that $57 \%$ is included in the appropriate category in the Interpretation of the product-moment, while $43 \%$ is a PowerPoint influencer factor Determining the degree of non-correlation

\section{REFERENCES}

Anomeisa, A. B., \& Ernaningsih, D. (2020). Media Pembelajaran Interaktif menggunakan PowerPoint VBA pada Penyajian Data Berkelompok. Jurnal Pendidikan Matematika Raflesia, 5(1), 17-31.

Asriningsih, N. W. N., Sujana, I. W., \& Darmawati, I. G. A. P. S. (2021). Penerapan Model Discovery Learning Berbantuan Media Powerpoint Meningkatkan Hasil Belajar IPS Siswa SD. Mimbar Ilmu, 26(2).

Astiti, N. K. A., Kristiantari, M. G. R., \& Saputra, K. A. (2021). Efektivitas Model Pembelajaran Discovery Learning Dengan Media Powerpoint Terhadap Hasil Belajar IPA Siswa SD. Journal of Education Action Research, 5(3), 409-415.

Aziz, I. N., \& Dewi, Y. A. S. (2020). The Use Of Powerpoint As Media Of Language Teaching On Students'speaking Skill. Humanities \& Social Sciences Reviews, 8(1), 344-358.

Baker, J. P., Goodboy, A. K., Bowman, N. D., \& Wright, A. A. (2018). Does teaching with PowerPoint increase students' learning? A meta-analysis. Computers \& Education, 126, 376-387.

Ch, C. (2021). Peran Guru Dalam Meningkatkan Minat Belajar Pendidikan Kewarganegaraan Menggunakan Media Flashcard Powerpoint Di SDN Berbah 2 Sleman. Jurnal Perseda: Jurnal Pendidikan Guru Sekolah Dasar, 4(1), 46-50.

Damayanti, P. A., \& Qohar, A. (2019). Pengembangan Media Pembelajaran Matematika Interaktif Berbasis Powerpoint pada Materi Kerucut. Kreano, Jurnal Matematika KreatifInovatif, $10(2), 119-124$.

Deviana, M., Subekti, E. E., \& Kuswandari, K. (2021). Peningkatan Hasil Belajar IPA pada Pembelajaran Tema 9 Melalui Model Discovery Learning Berbantuan Media Powerpoint bagi Siswa Kelas V SDN 2 Tanggung. Jurnal Paedagogy, 8(3), 345-350.

Dewi, M. D., \& Izzati, N. (2020). Pengembangan media pembelajaran powerpoint interaktif berbasis rme materi aljabar kelas vii smp. Delta: Jurnal Ilmiah Pendidikan Matematika, 8(2), 217226. 
Dwiono, R., Rochsantiningsih, D., \& Suparno, S. (2018). Investigating the integration level of information and communication technology (ICT) in the English language teaching. International Journal of Language Teaching and Education, 2(3), 259-274.

Efendi, D. N., Supriadi, B., \& Nuraini, L. (2021). Development of the powerpoint animation learning media on the heat topic. Gravity: Jurnal Ilmiah Penelitian dan Pembelajaran Fisika, 7(2).

Gunawan, H., \& Zinnurain, Z. (2019). Pengaruh Penggunaan Media Ms Powerpoint Berbasis Game Terhadap Hasil Belajar Siswa.Jurnal Teknologi Pendidikan: Jurnal Penelitian dan Pengembangan Pembelajaran, 3(1), 11-19.

Hadiyanti, K. W., \& Widya, W. (2018). Analyzing the values and effects of powerpoint presentations. LLT Journal: A Journal on Language and Language Teaching, 21(Suppl), 8795 .

Hikmah, S. N., \& Maskar, S. (2020). Pemanfaatan aplikasi microsoft powerpoint pada siswa smp kelas viii dalam pembelajaran koordinat kartesius. Jurnal Ilmiah Matematika Realistik, 1(1), 15-19.

Irfan, I., Muhiddin, M., \& Ristiana, E. (2019). Pengembangan Media Pembelajaran IPA Berbasis Powerpoint di Sekolah Dasar. Indonesian Journal of Primary Education, 3(2), 16-27.

Kresnadi, H. (2021). The Use of PowerPoint Slide Media to Improve Student Learning Outcome In Mathematics Learning. JP2D (Jurnal Penelitian Pendidikan Dasar) UNTAN, 4(2), 44-53.

Kusrini, K., Supriyadi, S., Bahri, S., Palittin, I. D., Rahayu, M., Silubun, H. A., \& Loupatty, M. (2018). Efektivitas model pembelajaran discovery learning berbantuan media powerpoint untuk meningkatkan hasil belajar siswa. Musamus Journal of Science Education, 1(1), 027-032.

Mansour, F. S. O. A., \& Odeh, F. S. (2019). The Impact of Using PowerPoint Presentations on Students Achievement and Information Retention in Teaching English Language at Public Schools in Amman (Doctoral dissertation, Middle East University).

Marpanaji, E., Mahali, M. I., \& Putra, R. A. S. (2018, December). Survey on how to select and develop learning media conducted by teacher professional education participants. In Journal of Physics: Conference Series (Vol. 1140, No. 1, p. 012014). IOP Publishing.

Ningsih, Y. (2020). Peningkatan Hasil Belajar Siswa Kelas X MIPA SMAN 1 Lubuklinggau melalui Penggunaan Media Powerpoint.Lentera Sriwijaya: Jurnal Ilmiah Pendidikan Matematika, 2(2), 64-72.

Nugraha, F. A., Nur'aeni, E., Suryana, Y., \& Muharram, M. R. W. (2021). Efektivitas Media Powerpoint dalam Pembelajaran Materi Luas Daerah Segitiga untuk Meningkatkan Minat Belajar Peserta Didik di Sekolah Dasar. EDUKATIF: JURNAL ILMU PENDIDIKAN, 3(5), 2760-2768.

Octaviana, S., \& Setiawan, Y. (2019). Meningkatkan minat belajar kelas IV sekolah dasar menggunakan media powerpoint berdasarkan kerangka kerja TPACK. Jurnal Pendidikan Tambusai, 3(3), 1150-1159.

Pateşan, M., Balagiu, A., \& Alibec, C. (2018, June). Visual aids in language education. In International Conference Knowledge-Based Organization (Vol. 24, No. 2, pp. 356-361).

Prayitno, P., \& Mardianto, M. F. F. (2020). Peningkatan Hasil Evaluasi Pembelajaran Daring saat Pandemi Covid-19 Berdasarkan Media Powerpoint Interaktif. MUST: Journal of Mathematics Education, Science and Technology, 5(2), 171-181.

Rozali, D., \& Ramadan, Z. H. (2021). Learning" Heat and Its Transfer" for Class V Students with PowerPoint Learning Media. International Journal of Elementary Education, 5(2).

Salmiah, S., Fatah, A., \& Purnamawati, P. (2021). Efektivitas Penggunaan Media Powerpoint dalam Meningkatkan Hasil Belajar Siswa Pada Mata Pelajaran Penerapan Konsep Mutu Hasil Pertanian. Jurnal Pendidikan Teknologi Pertanian, 2, 1-6.

Suriati, S., Bahri, A., \& Agustan, A. (2020). The Effect Of The Use Of PowerPoint Learning Media On Motivation And Cognitive Learning Outcomes In Science Learning For Class Iv Sdn 39 Students Often In Soppeng District. Jurnal Dikdas, 8(1), 71-86.

Susanti, E., Ritonga, M., \& Bambang, B. (2020). Pengaruh Penggunaan Media Powerpoint Terhadap Minat Belajar Bahasa Arab Siswa. Arabiyatuna: Jurnal Bahasa Arab, 4(1), 179-191.

Syaepudin, S., \& Juhji, J. (2020). The Effect of Using Powerpoint Media on Student Learning Outcomes in the Material Adaptation of Living Things. Pedagogi: Jurnal Penelitian Pendidikan, $7(1)$.

Utami, N., Khairuddin, K., \& Mahrus, M. (2020). Perbedaan Hasil Belajar Biologi Siswa pada Penggunaan Media Video dengan Media Powerpoint Melalui Pembelajaran dalam Jaringan 
(Daring) di SMAN 3 Mataram Tahun Ajaran 2020/2021. Jurnal Ilmiah Profesi Pendidikan, 5(2), 96-101.

Utami, S. (2021). Pemanfaatan copvid (convert powerpoint to video) sebagai media pembelajaran untuk meningkatkan hasil belajar siswa dalam pembelajaran jarak jauh. LJESE: Linggau Journal of elementary school education, 1(1), 1-7.

Tsai, M. C., Shen, P. D., Chen, W. Y., Hsu, L. C., \& Tsai, C. W. (2020). Exploring the effects of webmediated activity-based learning and meaningful learning on improving students' learning effects, learning engagement, and academic motivation. Universal Access in the Information Society, 19(4), 783-798.

Widodo, H., Cahyadi, N. T., \& Sari, D. P. (2021). Upaya Peningkatan Hasil Belajar PPKn melalui Penggunaan Media Pembelajaran Powerpoint pada Siswa Kelas VI C SD Negeri 064025 Medan. AL-IRSYAD, 11(1), 155-165.

Wulandari, M. (2017). Fostering learning autonomy through the implementation of flipped learning in language teaching media course. International Journal of Indonesian Education and Teaching (IJIET), 1(2), 194-205.

Yuliana, I., \& Hastiana, Y. (2019). Peningkatan Kemampuan Kognitif Siswa Melalui Metode Praktikum dengan Media Powerpoint Interaktif. Didaktika Biologi: Jurnal Penelitian Pendidikan Biologi, 3(1), 19-25. 